\title{
Mapping of Permanent Preservation Areas on Hilltops: Technical Issues
}

\author{
Guilherme de Castro Oliveira ${ }^{1}$ (D), Elpidio Inacio Fernandes Filho ${ }^{1}$ (D), \\ Márcio Rocha Francelino ${ }^{1}$ (1) \\ ${ }^{1}$ Universidade Federal de Viçosa (UFV), Viçosa, MG, Brasil \\ Departamento de Solos
}

\begin{abstract}
Some technical issues that are inherent to the mapping of permanent preservation areas (PPAs) on hilltops in Brazil have not yet been properly regulated. This results in disparities in mapping an area depending on the technique used. This paper presents a case study that exposes the influence of the topographic database, mapping scale, and method of measuring the average slope on the results obtained. The total PPAs mapped on hilltops vary significantly as a result of these factors. Subjectivity in applying legislation leads to legal uncertainty, which can be resolved by establishing precise, complementary regulations on the issue. Accordingly, it is proposed that the method of measuring the mean slope and mapping scale should be defined by regulation.
\end{abstract}

Keywords: Law 12,651, forestry laws, new Forest Code, geographic information system. 


\section{INTRODUCTION AND OBJECTIVES}

The mapping of permanent preservation areas (PPAs) on hilltops involves technical issues of cartography and geoprocessing that hitherto have received scant objective attention among researchers. There are uncertainties regarding the consistency of the cartographic products used and the subjective interpretations of the law; those factors can lead to different results and underestimation of mapped areas in this PPA category. Some advances have been observed in the regulations complementary to Law 12,651 (Brasil, 2012), such as Resolution no. 93 of October $24^{\text {th }}, 2014$ (Inea, 2014), which establishes a semi-automated methodology for delimiting these PPAs in the state of Rio de Janeiro.

According to current rules, delimitation of PPAs on hilltops is feasible only in computational environments through the use of digital elevation models (DEMs) and geoprocessing tools; this is due to the requirement to establish an average hill slope (Francelino \& Silva, 2014). However, it is necessary to determine the reliability of the maps produced using such techniques (Oliveira \& Fernandes Filho, 2016).

In addition to the uncertainty regarding the accuracy of DEMs, Law 12,651 (Brasil, 2012) contains some omissions that lead to further uncertainties. For example, through a lack of definition as to how the average hill slope should be calculated, the surveyor must select the method to use and the number of observations needed for calculation. The surveyor also chooses the locations for slope sampling-whether in the field or by geographic information system (GIS). In relation to previous legislation, the impacts of the change in criteria for measuring the hill slope are discussed by Francelino \& Silva (2014).

The present study had three main objectives: (1) to evaluate the effect of using different databases in mapping PPAs on hilltops; (2) to assess the importance of each criterion (mean slope and height) in the total area mapped through scenario simulation by changing the value required for each; and (3) to evaluate the effect of the mapping scale on the delimitation of PPAs. It is expected that our results can contribute to the drafting of regulations for the New Forest Code (NCF) and thus provide greater legal certainty in the field.

\section{MATERIALS AND METHODS}

\subsection{Study area}

For this study, we chose a $1,000-\mathrm{km}^{2}$ area that includes Serra do Gandarela National Park (Parna) in northeastern Quadrilátero Ferrífero in the state of Minas Gerais (Figure 1). The topography is very uneven and intensely dissected. There are elevations with concave profiles and narrow tops interspersed by embedded valleys; also, there is a restricted occurrence of embedded colluvial ramps (Carvalho Filho et al., 2010).

\subsection{Databases and software}

For the mapping, we used four free DEMs with different space resolutions: ASTER GDEM, $30 \mathrm{~m}$ (NASA et al., 2009); SRTM, $90 \mathrm{~m}$ (NASA, 2013); Topodata, 30 m (Valeriano \& Rossetti, 2012); and IBGE (1977a, 1977b, 1977c, 1979). The DEM produced with the IBGE data was created by interpolating the contour lines (obtained from 1:50,000 planialtimetric maps) with 10-m spatial resolution, using the topogrid algorithm (topo to raster) of ArcGIS 10.1 software (ESRI, 2012) without hydrologic conditioning. The four charts were combined by manual editing in the GIS (Figure 1).

We used a digital terrain model (DTM) with 2-m spatial resolution as reference for the analyses related to the mapping scale. The DTM was produced through point clouds created by the Airborne Light Detection and Ranging (LiDAR) system. The equipment used was the ALS50 (Leica Geosystems, Switzerland), with $70^{\circ}$ opening and up to $150 \mathrm{kHz}$ frequency. To attain the minimum quantity of 4 points $/ \mathrm{m}^{2}$, we conducted the profiling at flight altitudes of $2,340 \mathrm{~m}-3,040 \mathrm{~m}$. The data were processed and classified for removal of surface objects. To produce the DTM, we then converted these point clouds into vector format by resampling. The automated mapping of PPAs on hilltops was performed according to Oliveira \& Fernandes Filho (2016). We undertook data processing using the ArcGIS 10.1 program.

\subsection{Adjustments in digital slope models}

Due to loss of information in low-resolution digital slope models (DSMs), we implemented a measure to make them more suitable for mapping PPAs. A cutoff point was defined for each resolution in the reclassification 

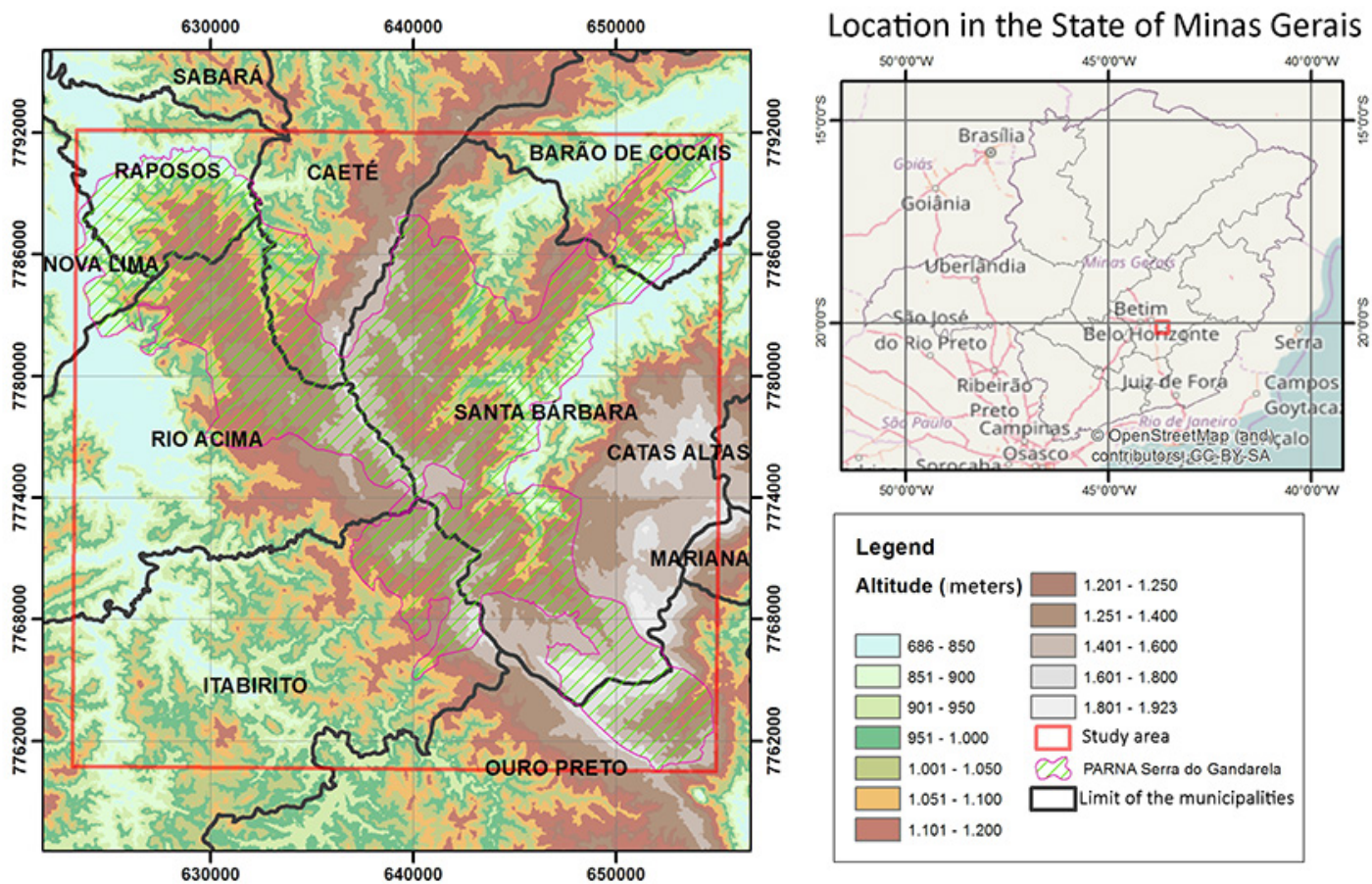

Figure 1. Study area location, covering the limits of Serra do Gandarela National Park, MG.

of the DSMs; that resulted in the same area mapped in the LiDAR model as was used as a reference.

For adjustment of the calibration curve, we created DEMs with resolutions of $2 \mathrm{~m}-90 \mathrm{~m}$ by resampling the original laser survey data. We took the 2 -m resolution DEM as the reference model. We then generated the $2-\mathrm{m} \mathrm{DSM}$ and calculated the area with a slope $>25^{\circ}$; that value corresponded to the minimum average slope defined by the NCF for an elevation to be considered a hill. Subsequently, for each of these DEMs with a cell $>2 \mathrm{~m}$, a DSM was created and the slope limit was iterated until we obtained approximately the same hill area as in the reference DSM. This final value was taken for each resolution used to adjust the regression equation, employing the slope as a dependent variable and the DSM cell size 'as an independent variable.

\subsection{Simulation of scenarios}

We performed mapping using the criteria established in Law 12,651 (average slope $>25^{\circ}$ and height $>100 \mathrm{~m}$ ); to assess the influence of each criterion in the total area classified as a PPA, we also created a simulation where those values were altered. The average slope required was $25^{\circ}-10^{\circ}$ in $5^{\circ}$ decreases; the height was $100 \mathrm{~m}-$ $50 \mathrm{~m}$ in 10- $\mathrm{m}$ decreases. In addition, the combination of those values was evaluated. As noted above, we also considered the reclassified slope according to the appropriate value in relation to the cell size of each DEM. Values were used for digital slope models corresponding to $25^{\circ}$ in the best resolution database.

Two different methods were employed to measure the slope (Figure 2). With Method 1, we measured the slope of imaginary lines linking the hilltop to numerous points located above the level that defined its base (Brasil, 2012). In Method 2, we produced a slope map using the Slope function of ArcGIS 10.1 and then calculated the cell average for each hill.

\subsection{Mapping scale and saddle points}

We used the relationship between the DEM resolution for the mapping and analyzed the number, spatial distribution, and quality of the saddle points mapped; with the latter, we considered the difference in altitude between the hilltop and its nearest saddle point. The saddle points were determined according to the methodology of Oliveira \& Fernandes Filho (2016). 


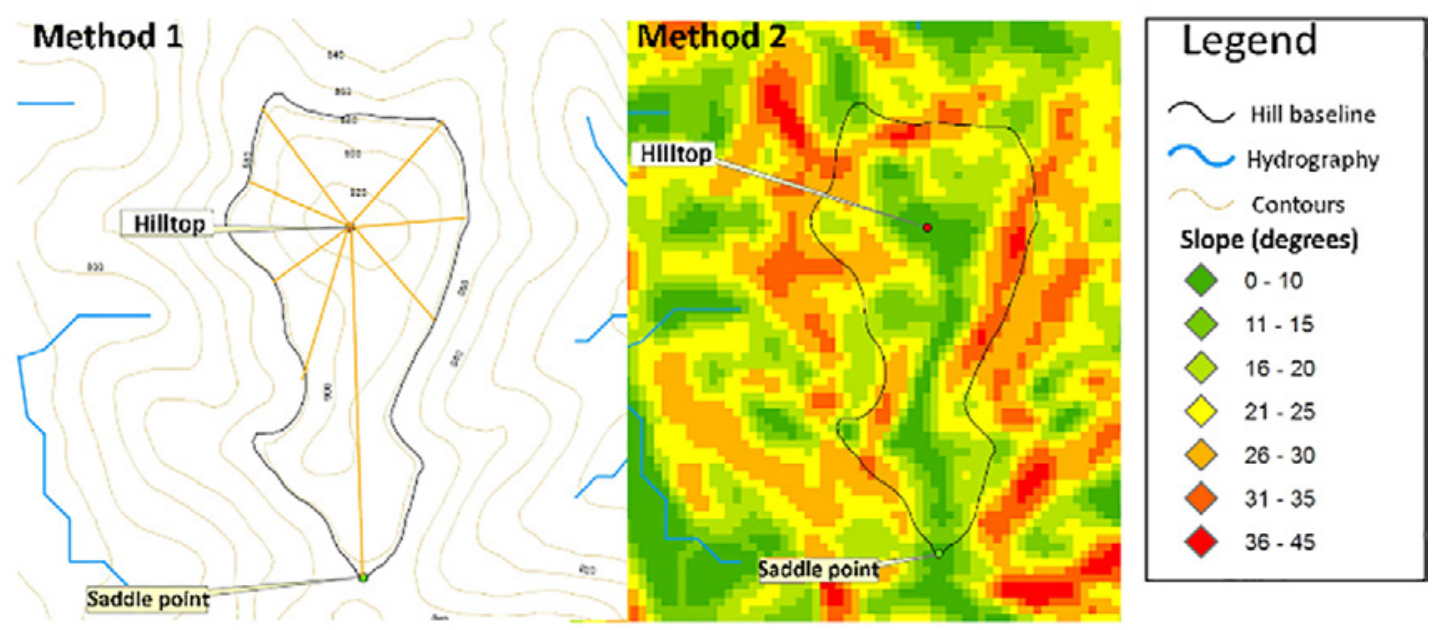

Figure 2. Methods of calculating mean slope: in the left, slope calculated by lines connecting the summit to the baseline (Method 1); in the right, slope calculated by the mean value of the cells contained in the base area of the hill (Method 2).

We employed LiDAR data, represented in matrices of increasing cell size $(5 \mathrm{~m}-90 \mathrm{~m})$, through a generalization by resampling the DEM with 2-m resolution.

We selected the saddle points closest to the elevations and exported them to a new feature, whereby the difference in the altitude of the hilltop and that of the saddle point was calculated. Thus, we determined the hill height defined by the saddle point level in accordance with the law. We verified the spatial distribution pattern of the saddle points geostatistically using the nearestneighbor method: that considers the average distance of the points to their neighbors and compares them with the average distance expected in a normal distribution. The distribution can be classified as grouped, random, or scattered (Isaaks \& Srivastava, 1989). We performed the geostatistical analyses using ArcGIS 10.1.

\section{RESULTS AND DISCUSSION}

\subsection{Adjustments in digital slope models}

With 2-m spatial resolution, the total area with slopes $\geq 25^{\circ}$ was 503 ha in the DSMs. To find an approximate area, the lower the spatial resolution of the DSMs generated by resampling of the former, the lower is the slope value established as the threshold. For example, for DEMs with 10-m, 30-m, and 90-m resolution, the resulting slope in the same area (in terms of magnitude) was $21^{\circ}, 17^{\circ}$, and $12^{\circ}$, respectively. We used the values to delineate a curve (Figure 3). This adjustment function was then employed to determine the slope thresholds for the IBGE, ASTER, SRTM, and Topodata models.

The application of that adjustment was coherent: the areas obtained in the adjusted reclassification had greater spatial coincidence with those in the reference model (Figure 4). Without such adjustment, areas with a slope $>25^{\circ}$ are greatly reduced in the lower resolution slope models; consequently, they cannot be considered suitable for mapping PPAs on hilltops. Thus, it is necessary to make a correction to compensate for the effect of low spatial resolution. The limitation of DTMs in representing areas with a more pronounced gradient is well known (Carlisle, 2005; Chang \& Tsai, 1991). This was also verified in the context of PPA mapping by Alvares \& Henkes (2012), who found that the use of SRTM DEM was impractical for mapping PPAs with slopes $>45^{\circ}$.

Although the Topodata and ASTER models have the same resolution, the former presents fewer areas with a slope $>25^{\circ}$. This can be explained by the fact that the Topodata DEM originates from the 90-m SRTM model, which was interpolated to $30 \mathrm{~m}$ by means of kriging (Valeriano \& Rossetti, 2012). This interpolation has limitations in representing the detail of the relief present in a DEM with improved resolution. However, some areas with a higher slope appeared in the interpolated DEM for a smaller cell size. Therefore, the Topodata DEM presented more areas with slopes $>25^{\circ}$ than the 


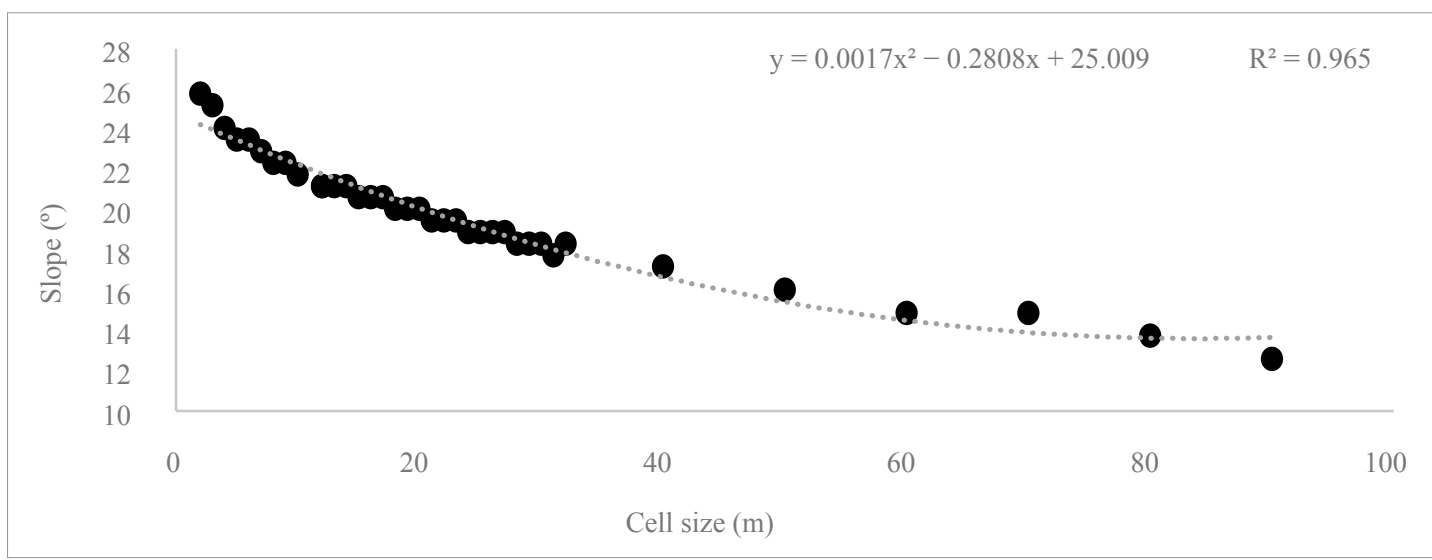

Figure 3. Slope threshold to map areas of equivalent magnitude, in function of spatial resolution of digital slope models produced by resampling of LiDAR data. y: Slope; $\mathrm{x}$ : Cell-size; $\mathrm{R}^{2}$ : coefficient of determination.

SRTM, but fewer than the ASTER DEM (Figure 4). Moreover, the ASTER and SRTM DEMs derive from different acquisition methods (stereoscopy and radar, respectively), which also leads to differences in the models.

\subsection{Mapping of PPAs and scenario simulation}

The total areas mapped with each database is presented in Table 1 . It is evident that considering the criteria established in the NCF (Brasil, 2012), the mapped area was small in all the DEMs - regardless of the method used to calculate the slope. For the IBGE and ASTER DEMs, Method 2 (mean slope values in the cells) resulted in a higher total area classified as PPAs on hilltops. For the Topodata DEM, no PPA was found with either of the methods. Unlike the others, for the SRTM DEM, Method 1 (without adjustment) resulted in more mapped areas. This result is a consequence of

\section{Areas of slope greater than $25^{\circ}$ mapped on the original resolution DSM}
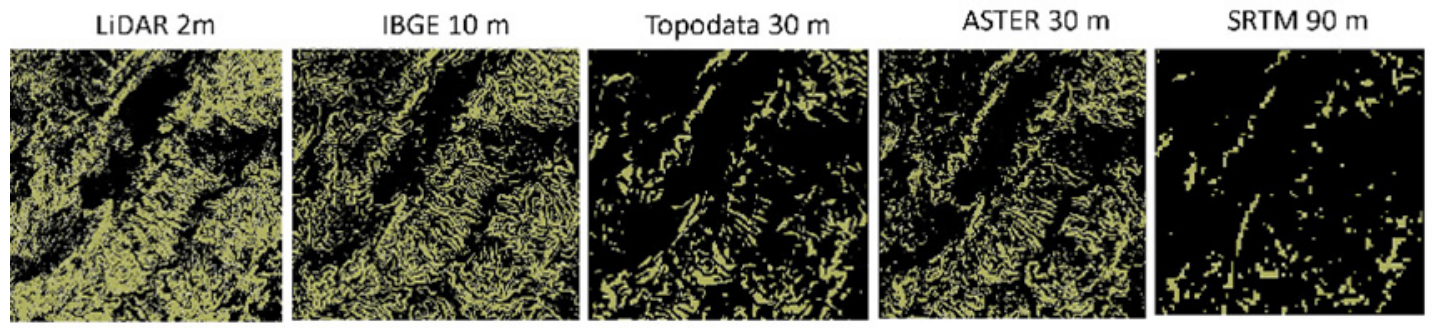

\section{Slope applied to map an equivalent area}

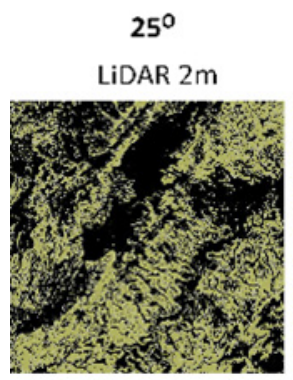

$21^{\circ}$

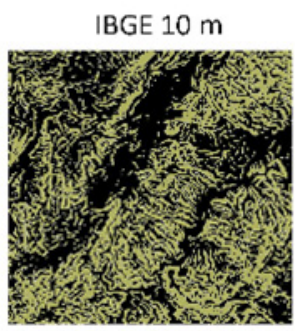

$17^{\circ}$

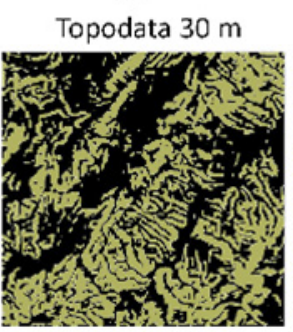

$17^{\circ}$ ASTER $30 \mathrm{~m}$

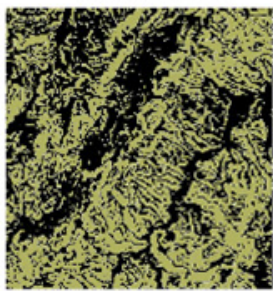

$12^{\circ}$

SRTM $90 \mathrm{~m}$

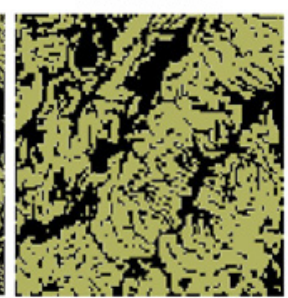

Figure 4. In yellow, areas with slopes greater than $25^{\circ}$ in the original DSM (above) and with slope reclassified by the adjusted value by regression (below), to reach an equivalent area. 
low-resolution DEMs being unable to express highslope areas with good quality. Therefore, with a method where the mean slope of the pixels is calculated, the resulting values are low.

When reclassifying the slope, adjusted according to the resolution of the DEMs, both methods of slope calculation showed a significant increase in the areas classified as PPAs. Thus, limiting factors in the classification are uncertain regarding the slope representation and the great influence of the slope criterion in mapping the PPAs.

Compared with the other models, there was clearly a discrepancy in the total area mapped with the SRTM DEM: it exceeded 400 ha when the slope values were adjusted to compensate for the DEM resolution for both Methods 1 and 2. Mapping PPAs on hilltops using lowresolution DEMs tends to underestimate the total PPAs (Victoria, 2010). However, with the application of slope adjustment, the result was different. One reason is that because of the larger cell size, the SRTM model represents only the deepest saddle points in the topographic profile (Figure 5); that causes the base level of the hills (saddle point) to move away from the summit. As a consequence, there is a considerable increase in the areas delimited by the upper third of the elevations: adjacent hills are grouped as only one (Oliveira, 2015).

Another reason is the inclusion error in the slope adjustment method when considering cells with a slope $>12.4^{\circ}$ as equivalent to $25^{\circ}$ in the SRTM DEM. Many areas that were previously not considered became mistakenly classified as PPAs and - by having an individually larger area - led to a larger total area being mapped.

For all the databases evaluated, Method 2 for calculating the mean slope (mean of the cells) led to a larger number of areas classified as PPAs when adjusted according to DEM resolution. This demonstrates that the average cell method is more sensitive to the loss of information. It is also worth noting that with Method 2, no area was mapped with the SRTM and Topodata DEMs without slope correction. The largest PPA on the hilltop was mapped with the SRTM DEM at $65.8 \mathrm{ha}$; the smallest area ( $0.1 \mathrm{ha}$ ) was mapped with the ASTER DEM. Adjusting the slope to compensate for loss of information by DEM cell size, increased the number of areas classified as PPAs and also included smaller areas that were not previously mapped.

Except for the SRTM data, the total number of PPAs mapped with the different DEMs was closer to that with the application of slope adjustment. Thus, by considering the loss of information in the DEMs with less spatial resolution and compensating that through an equivalent value for each resolution, the DEMs became more equal by attenuating the scale effect of each. It resulted in more similar maps produced using different databases.
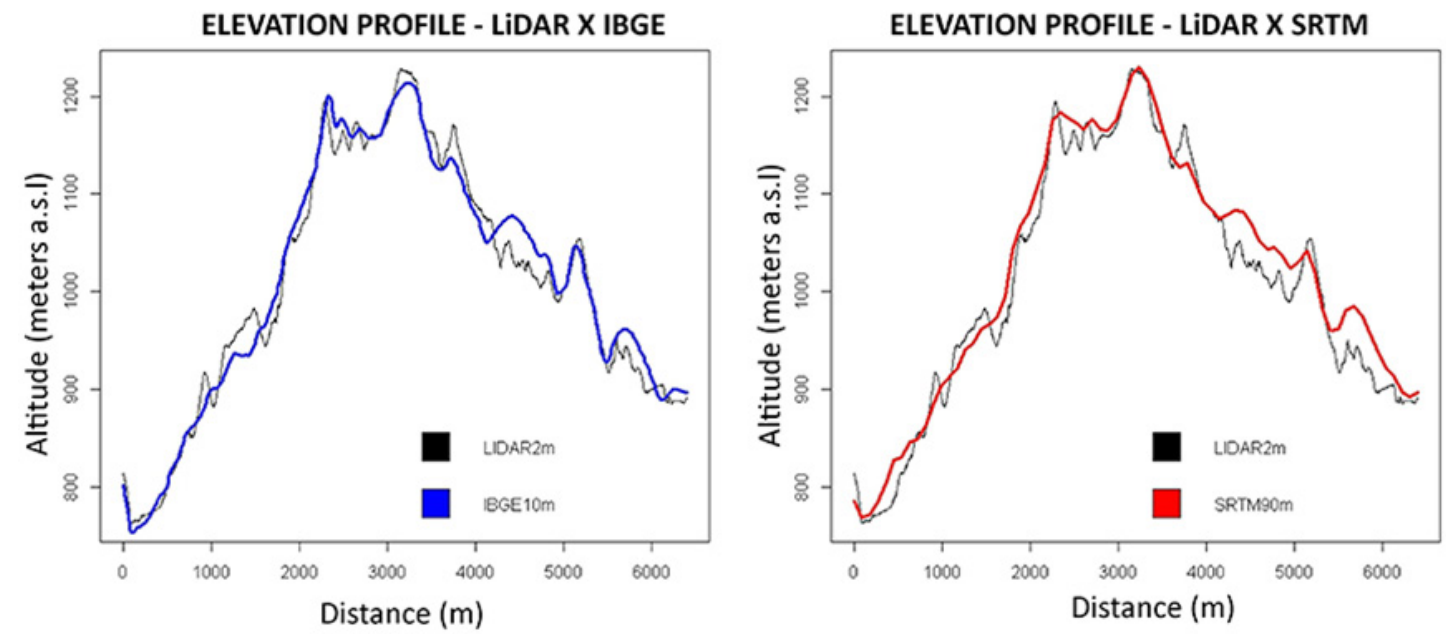

Figure 5. Elevation profiles extracted from IBGE and SRTM DEMs and compared with the LiDAR DEM. Low-resolution DEMs do not represent shallower saddle points, leading to agglutination of adjacent elevations. a.s.l.: above sea level. 
The results of the scenario simulation appear in Table 1: larger increments of mapped area are evident when the required mean slope decreases. However, reducing the required height produced less significant gains in terms of total mapped area. Even in the simulation where the largest mapped area $(1,135.6 \mathrm{ha})$ was identified, that value corresponds to only $1.13 \%$ of the landscape analyzed. A strong geographic isolation of sites classified as PPAs on hilltops was also observed (Figure 6).

The results of the mapping were submitted to analysis of variance (Anova), considering the slope and height as factors and the total area mapped as the response variable. With this approach, we tried to determine which mapping criterion (height or slope) had a greater influence on the total PPAs mapped on hilltops. The Anova result appears in Table 2 for the two methods of calculating the mean slope.

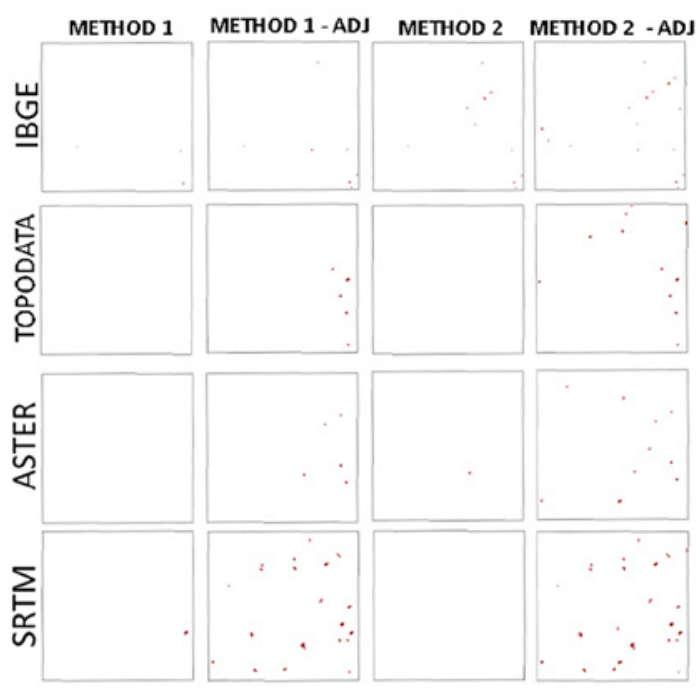

Figure 6. Distribution of the PPAs on tops of hills (in red) mapped in the study area with the different digital elevation models. ADJ: adjusted.

Table 1. Scenario simulation results.

\begin{tabular}{|c|c|c|c|c|c|c|c|c|c|c|}
\hline \multirow{2}{*}{$\begin{array}{l}\text { Height } \\
\text { (m) }\end{array}$} & \multicolumn{5}{|c|}{ Slope $\left({ }^{\circ}\right)$ - Method 1} & \multicolumn{5}{|c|}{ Slope $\left({ }^{\circ}\right)-$ Method 2} \\
\hline & 10 & 15 & 20 & 25 & $\begin{array}{l}\text { Adjusted } \\
\text { Slope }\end{array}$ & 10 & 15 & 20 & 25 & $\begin{array}{l}\text { Adjusted } \\
\text { Slope }\end{array}$ \\
\hline \multicolumn{11}{|l|}{ ASTER } \\
\hline 50 & 472.7 & 251.9 & 70.6 & 8.3 & 116.7 & 472.7 & 375.5 & 168.7 & 24.0 & 263.0 \\
\hline 60 & 374.9 & 226.6 & 66.3 & 8.3 & 112.4 & 374.9 & 324.8 & 163.9 & 24.0 & 237.3 \\
\hline 70 & 327.6 & 204.0 & 62.2 & 8.3 & 100.7 & 327.6 & 297.5 & 148.0 & 24.0 & 216.8 \\
\hline 80 & 267.7 & 173.6 & 57.3 & 6.5 & 87.7 & 267.7 & 258.9 & 123.7 & 22.2 & 178.1 \\
\hline 90 & 244.2 & 166.1 & 57.3 & 6.5 & 87.7 & 244.2 & 244.2 & 123.7 & 22.2 & 178.1 \\
\hline 100 & 169.1 & 113.6 & 35.1 & 0.0 & 48.5 & 186.4 & 186.4 & 71.1 & 11.4 & 120.4 \\
\hline \multicolumn{11}{|l|}{ IBGE } \\
\hline 50 & 554.1 & 314.0 & 74.4 & 20.4 & 46.9 & 613.7 & 497.4 & 211.2 & 71.5 & 138.7 \\
\hline 60 & 482.7 & 289.2 & 73.3 & 20.4 & 46.9 & 497.8 & 439.0 & 204.3 & 70.4 & 133.5 \\
\hline 70 & 419.8 & 257.7 & 67.1 & 20.4 & 43.0 & 419.8 & 392.1 & 179.9 & 66.5 & 119.6 \\
\hline 80 & 402.0 & 239.9 & 62.3 & 20.4 & 43.0 & 402.0 & 374.3 & 166.3 & 66.5 & 110.4 \\
\hline 90 & 381.1 & 230.7 & 56.4 & 17.4 & 40.0 & 381.1 & 353.4 & 160.4 & 60.5 & 104.5 \\
\hline 100 & 241.9 & 197.0 & 48.6 & 12.9 & 35.5 & 293.9 & 280.2 & 139.7 & 56.0 & 92.6 \\
\hline \multicolumn{11}{|l|}{ SRTM } \\
\hline 50 & 1045.9 & 408.2 & 91.3 & 37.9 & 722.5 & 1135.6 & 447.7 & 56.0 & 0.0 & 834.4 \\
\hline 60 & 955.4 & 386.8 & 85.6 & 35.4 & 680.5 & 1034.4 & 431.2 & 56.0 & 0.0 & 773.5 \\
\hline 70 & 834.4 & 331.6 & 69.9 & 35.4 & 582.6 & 896.1 & 380.2 & 51.8 & 0.0 & 682.2 \\
\hline 80 & 759.5 & 307.8 & 63.4 & 33.7 & 532.4 & 821.3 & 362.9 & 48.6 & 0.0 & 620.5 \\
\hline 90 & 718.4 & 283.1 & 52.7 & 33.7 & 500.3 & 780.1 & 329.2 & 48.6 & 0.0 & 579.3 \\
\hline 100 & 663.3 & 258.4 & 48.6 & 33.7 & 434.5 & 668.2 & 288.8 & 48.6 & 0.0 & 502.0 \\
\hline
\end{tabular}


Table 1. Continued...

\begin{tabular}{|c|c|c|c|c|c|c|c|c|c|c|}
\hline \multirow{2}{*}{$\begin{array}{c}\text { Height } \\
\text { (m) }\end{array}$} & \multicolumn{5}{|c|}{ Slope $\left(^{\circ}\right)$ - Method 1} & \multicolumn{5}{|c|}{ Slope $\left({ }^{\circ}\right)-$ Method 2} \\
\hline & 10 & 15 & 20 & 25 & $\begin{array}{l}\text { Adjusted } \\
\text { Slope }\end{array}$ & 10 & 15 & 20 & 25 & $\begin{array}{c}\text { Adjusted } \\
\text { Slope }\end{array}$ \\
\hline \multicolumn{11}{|c|}{ TOPODATA } \\
\hline 50 & 630.3 & 211.0 & 48.5 & 5.9 & 130.4 & 740.2 & 464.0 & 139.1 & 4.0 & 315.3 \\
\hline 60 & 530.6 & 180.9 & 46.6 & 4.0 & 118.9 & 592.7 & 415.0 & 126.2 & 4.0 & 285.8 \\
\hline 70 & 460.1 & 157.7 & 44.6 & 2.0 & 116.9 & 509.4 & 369.9 & 124.2 & 2.0 & 249.8 \\
\hline 80 & 396.6 & 138.5 & 39.4 & 0.0 & 106.6 & 396.6 & 313.0 & 113.9 & 0.0 & 230.6 \\
\hline 90 & 355.2 & 114.2 & 34.9 & 0.0 & 89.4 & 355.2 & 271.6 & 96.7 & 0.0 & 195.0 \\
\hline 100 & 262.6 & 97.4 & 34.9 & 0.0 & 82.4 & 287.2 & 215.4 & 89.7 & 0.0 & 157.7 \\
\hline
\end{tabular}

Hectares of PPAs on hilltops mapped with the four databases used. Values highlighted represent the mapped area considering the criteria defined in the law.

Table 2. Anova of the total area mapped, by the criteria of height and average slope.

\begin{tabular}{|c|c|c|c|c|c|}
\hline \multicolumn{6}{|c|}{ Method 1} \\
\hline Source of variation & DF & SQ & MS & $\mathbf{F}$ & $\operatorname{Pr}(>\mathbf{F})$ \\
\hline Height & 5 & 165,273 & 33,055 & 2,312 & 0.0506 \\
\hline Slope & 3 & $3,454,258$ & $1,151,419$ & 80,537 & $<2 \mathrm{e}-16^{* * *}$ \\
\hline Residual & 87 & $1,243,819$ & 14,297 & & \\
\hline \multicolumn{6}{|c|}{ Method 2} \\
\hline Source of variation & DF & SQ & MS & $\mathbf{F}$ & $\operatorname{Pr}(>\mathbf{F})$ \\
\hline Height & 5 & 271,132 & 54,226 & 3,173 & $0.0112^{*}$ \\
\hline Slope & 3 & $3,748,788$ & $1,249,596$ & 73,115 & $<2 \mathrm{e}-16^{* * *}$ \\
\hline Residual & 87 & $1,486,903$ & 17,091 & & \\
\hline
\end{tabular}

DF: degrees of freedom; SQ: sum of squares; MS: mean squares; F: F-statistic; Pr: probability of the F-statistic, ${ }^{\star}$ : significant at $5 \%$ level; ${ }^{* * *}$ : significant at $1 \%$ level.

The mean slope of the hills was the most limiting factor: it was significant at $99 \%$ probability with the two delimitation methods. With Method 1, the height criterion was not a significant factor; the limitation given by the slope was such that even when reducing the required height, there were no significant gains in the protected area. With the Method 2 results, there was a greater influence of the height criterion; the slope also had a great influence.

Regarding the methods used, Method 2 was more appropriate for slope calculation (mean values of the cells' slopes), since it resulted in a larger legally protected area with most of the DEMs tested. Lower computational costs and less technical complexity are the presented advantages of this method. The SRTM DEM is an exception, as discussed hereafter.

Summarizing, the total area mapped as PPAs on hilltops was more sensitive to the change in the average slope than with change in height. To corroborate this result, Francelino \& Silva (2014) proposed that instead of considering the average slope of the hill, it would be more appropriate to consider whether the line with the highest slope was $>25^{\circ}$ or not - which is an adaptation of the old Forest Code that was parameterized by the Conama Resolution no. 303 (Brasil, 2002). According to these authors, the change would result in larger PPAs mapped on hilltops.

\subsection{Mapping scale and saddle points}

There was a reduction in the number of saddle points mapped with the increase in the LiDAR DEM cell size (Table 3), which was accompanied by an increase in the average height of hills: the saddle points were more distant from the tops and assumed lower levels of relief, resulting in greater hill heights. In the LiDAR DEMs 
with high spatial resolution ( $5 \mathrm{~m}$ and $15 \mathrm{~m}$ ), the average height of the hills was below $10 \mathrm{~m}$, which indicates the existence of many saddle points unduly included in the mapping. At the lowest spatial resolution $(90 \mathrm{~m})$, only 72 saddle points were mapped; the mean height of the hills was $26.4 \mathrm{~m}$. This result is another reason for a larger total PPA area on hilltops with SRTM data.

It is evident that the number of saddle points resulting from mapping with a high-resolution DEM $(5 \mathrm{~m} \times 5 \mathrm{~m})$ was disproportionate to the other results; this reflects possible incompatibility of the high-resolution data with the scale of the studied phenomena. The results confirm the need to adapt the use of DEMs to their specific purpose. In the present study, the models with better spatial resolution, although more accurate, are inadequate for mapping PPAs on hilltops. That is because their micro-relief expression is strong, leading to a subdivision of the elevation domains that does not correspond either with the geomorphological reality or with what could be considered appropriate for the environmental and ecological functions expected of a PPA (Brasil, 2012; Tambosi et al., 2015).

With DEMs with a cell size starting at $30 \mathrm{~m}$, the number of saddle points mapped showed a small reduction compared with those of $5 \mathrm{~m}-15 \mathrm{~m}$, which suggests a minimum resolution limit for digital mapping. The abrupt increase in the number of saddle points reflects inadequate representation of the relief (Figure 7).

There was also an increase in the perimeter of the hills with a rise in the DEM cell size (that is, areas with a slope $\geq 25^{\circ}$ and minimum height of $100 \mathrm{~m}$ in relation to the level of the saddle point closest to the elevation); this means that, individually, the hills were more extensive at lower resolutions. The total hill area also increased up to 60-m resolution; from that point, the small number of delimited hills caused the total area to start decreasing (Figure 8). The polygons that defined the base of the hills resulting from mappings performed with DEMs of increasing order cell size appear in Figure 7. The images visually confirm that the DEM resolution used in the mapping led to very different results.

The geostatistical results are presented in Table 3 . The spatial distribution pattern of the mapped saddle points varied in the different resolutions, which may represent another criterion for defining the mapping scale. With very high spatial resolutions ( $5 \mathrm{~m}$ and $15 \mathrm{~m}$ ), the mapped saddle points presented a grouped spatial distribution pattern. That pattern became random in the mappings carried out with DEMs with resolution of $30 \mathrm{~m}-75 \mathrm{~m}$. At the lowest resolution tested $(90 \mathrm{~m})$, the distribution pattern was scattered.

The change in the spatial distribution patterns of the saddle points reflected the importance of scale in this mapping. The grouped pattern observed in the highresolution DEMs results did not constitute an adequate basis for measurement; it produced an inconsistent subdivision of the hills and-consequently-very small areas and a smaller total mapped area. By contrast, the scattered pattern observed in the low-resolution DEM indicated that with this scale, many domains were grouped even though they could be considered separately; that is not consistent with the rural reality: there, large PPAs are the responsibility of a small number of owners.

Table 3. Number of saddle points and height of the hills defined by them, mapped with digital elevation models with increasing cell sizes, from the LiDAR survey. Spatial distribution pattern of saddle points by the nearest neighbor method. The expected average distance is calculated based on a normal distribution pattern.

\begin{tabular}{ccccccccc}
$\begin{array}{c}\text { Cell size } \\
\left(\mathbf{m}^{2}\right)\end{array}$ & $\begin{array}{c}\text { Number } \\
\text { of saddle } \\
\text { points }\end{array}$ & Mean & $\begin{array}{c}\text { Hill height }(\mathbf{m}) \\
\text { Standard } \\
\text { Deviation }\end{array}$ & $\begin{array}{c}\text { Average } \\
\text { observed } \\
\text { distance }\end{array}$ & $\begin{array}{c}\text { Average } \\
\text { expected } \\
\text { distance }\end{array}$ & Z-score & p-value & Pattern \\
\hline 5 & 3,537 & 2.2 & 5 & 48.58 & 81.4 & -47.4 & 0.00 & Clustered \\
15 & 540 & 7.6 & 13.2 & 167.23 & 207.49 & -9.0 & 0.00 & Clustered \\
\hline 30 & 266 & 13.8 & 17.9 & 289.36 & 300.57 & -1.2 & 0.23 & Random \\
\hline 5 & 163 & 18.1 & 24.2 & 360.63 & 371.83 & -0.8 & 0.44 & Random \\
\hline 60 & 109 & 21.5 & 32.1 & 471.9 & 472.69 & 0.0 & 0.97 & Random \\
\hline 75 & 87 & 25.9 & 33.9 & 520.3 & 515.96 & 0.2 & 0.87 & Random \\
\hline 90 & 72 & 26.4 & 34.2 & 640.18 & 573.82 & 1.92 & 0.05 & Dispersed \\
\hline
\end{tabular}




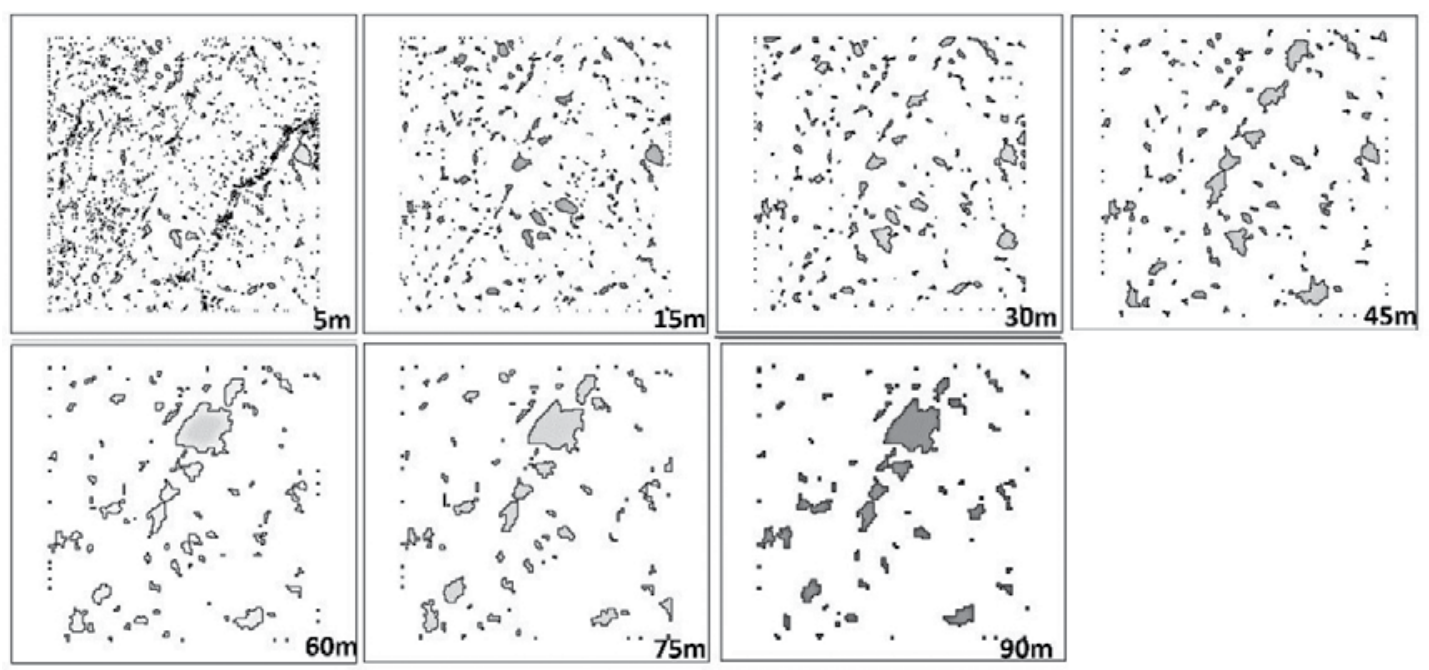

Figure 7. Areas defined as hill bases, mapped with LiDAR DEMs with different spatial resolutions.

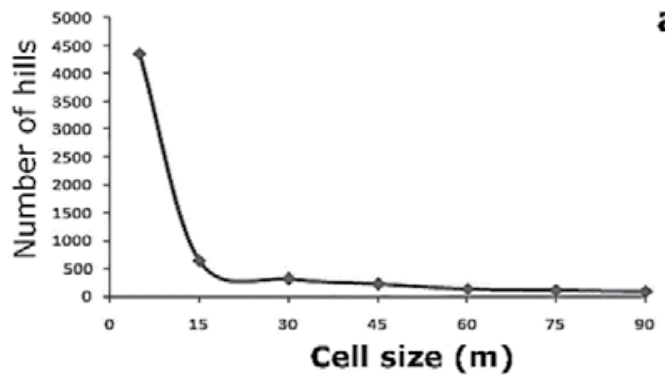

a

b
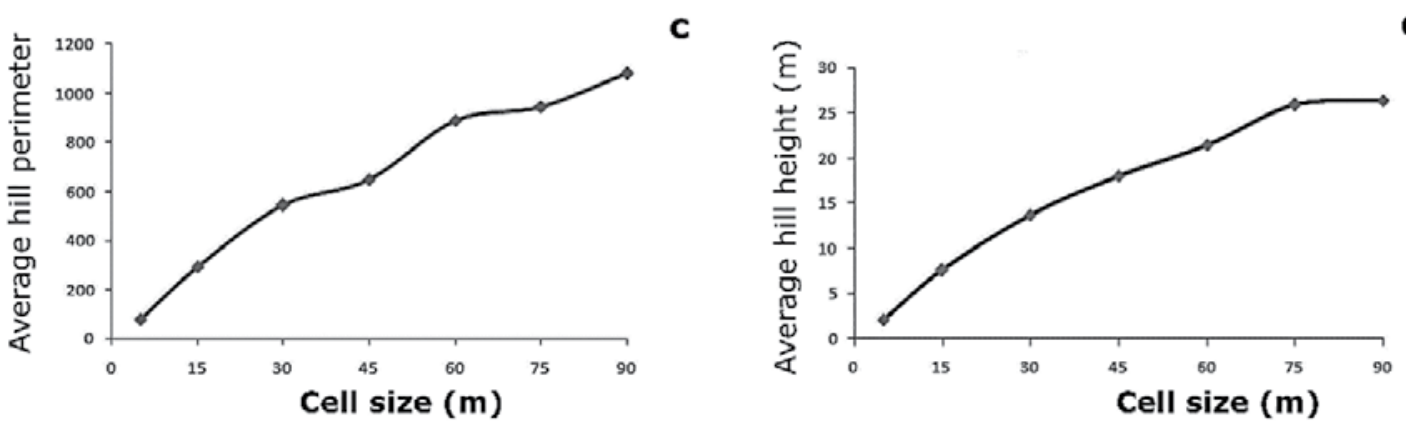

Figure 8. Relationship between the resolution of the digital elevation model and: a) number of hills; b) total area of the hills; c) average perimeter of the hills; and d) average height of the hills.

Thus, the ideal scenario would be one in which the PPAs on hilltops had an adequate size and spatial distribution that favored their connectivity with other protected areas. However, despite the obvious importance of the mapping scale, the NCF does not address this topic; the result is a large shortfall that has caused legal uncertainty around the issue and made the law ineffective. If the scale of the used data is decisive in the mapping result, it is essential for it to be regulated. Even in mapping performed in the field, to consider or not a depression as a saddle point is a very subjective question, the criteria for which are determined by the surveyor.

Studies published in recent years have shown a small number of PPAs on hilltops or even their complete absence, which is in accordance with the 
findings of the present study (Aguiar et al., 2018; Fernandes et al., 2015; Francelino \& Silva, 2014; Oliveira \& Fernandes Filho, 2016; Soares-Filho et al., 2014). As shown, the methodology and input data of the model are of paramount importance for mapping PPAs on hilltops.

However, recent studies either provide few details of the methodology used or apply techniques that were developed for previous legislation - or even legal misinterpretations (Eugenio et al., 2017; Fernandes et al., 2015; Soares-Filho et al., 2014). For example, the method used by Soares-Filho et al. (2014) considered as the base of the hill the minimum altitude of the elevations; that caused the total area classified as PPAs on hilltops to be overestimated and exceeded the hill limits defined in the NCF.

\section{CONCLUSIONS}

Two main points regarding the mapping of PPAs on hilltops should be emphasized: (1) the need to define the method for calculating the average slope (due to the divergent results with the two methods used in the present study); and (2) defining an appropriate mapping scale. We found that the scale, represented by the DEM resolution, defined the results: it affected the location of the saddle points and calculation of the mean slope. The absence of well-defined criteria leaves room for subjectivity when interpreting the law and in its practical application.

Even if the requirements of mean slope and height for the delimitation of PPAs on hilltops were reduced, the resulting areas would occupy a small fraction of the territory; this would compromise their function as shaping gene flows in the landscape. In future studies, we would recommend evaluating the degree of connectivity of this class of PPA with others, relative to the mapping scale.

This paper presented a method of overcoming the imprecision of digital slope models by determining slope values in relation to their cell size at the time of models' reclassification. The visual analysis of the maps indicates the potential of this method; however, it requires further careful evaluation. More in-depth studies are needed with more robust results to ascertain their consistency and application for different purposes, considering omission and commission errors. For each type of relief, a specific curve also would need to be adjusted using a high-spatial-resolution DEM, which would then allow application of the method. With this adjustment, low-spatial-resolution DEMs could lead to a larger mapped area: they tend to group adjacent hills, increasing the area of the upper third of the elevations and also their height.

The number and spatial distribution patterns of mapped saddle points could serve as a reference for defining the mapping scale of PPAs on hilltops. According to those indicators, for the studied area, the adequate spatial resolution is apparently $30 \mathrm{~m}-75 \mathrm{~m}$.

In view of the results, the need for detailed regulations to complement the NCF is confirmed by defining parameters for the delimitation of PPAs using GIS. The current text in regulations permits multiple interpretations, which can lead to different and conflicting results in the delimitation of PPAs on hilltops, thereby causing legal ambiguity.

\section{SUBMISSION STATUS}

Received: 6 Mar., 2017

Accepted: 7 Nov., 2018

\section{CORRESPONDENCE TO}

\section{Guilherme de Castro Oliveira}

Universidade Federal de Viçosa (UFV), Departamento de Solos, Av. Peter Henry Rolfs, s/n, CEP 36570-000, Viçosa, MG, Brasil e-mail: guilhermecastrol86@gmail.com

\section{FINANCIAL SUPPORT}

The present study was performed with the support of Coordenação de Aperfeiçoamento de Pessoal de Nível Superior (Capes) - Financing Code 001.

\section{REFERENCES}

Alvares RP, Henkes JA. Áreas de preservação permanente em encostas: delimitação através de dados SRTM. Gestão \& Sustentabilidade Ambiental 2012; 1(1): 198-254. 10.19177/rgsa.vle12012198-254

Aguiar W, Sampaio SC, Paisani JC, Reis RR. Implications for peak flows of the Marrecas river basin due to changes in the Brazilian forest code. Engenharia Agrícola 
2018; 38(2): 277-283. 10.1590/1809-4430-eng.agric. v38n2p277-283/2018

Brasil. Lei no 12.651 , de 25 de maio de 2012. Diário Oficial da República Federativa do Brasil, Brasília, DF (2012 May 28); Sec. 1: 16.

Carlisle BH. Modelling the spatial distribution of DEM error. Transactions in GIS 2005; 9(4): 521-540. 10.1111/j.1467-9671.2005.00233.x

Carvalho Filho A, Curi N, Shinzato E. Relações solo paisagem no Quadrilátero Ferrífero em Minas Gerais. Pesquisa Agropecuária Brasileira 2010 [cited 2019 May 20]; 45(8): 903-916. Available from: https://bit.ly/2HsYjbb

Chang KT, Tsai BW. The effect of DEM resolution on slope and aspect mapping. Cartography and Geographic Information Systems 1991; 18(1): 69-77. $10.1559 / 152304091783805626$

Conselho Nacional de Meio Ambiente - Conama. Resolução no 303, de 20 de março de 2002. Diário Oficial da República Federativa do Brasil, Brasília, DF (2002 May 13); Sec. 1: 68.

Environmental Systems Research Institute - ESRI. ArcGIS Desktop. Release 10.1 [software]. 2012 Oct. 24 [cited 2019 May 20]. Available from: https://bit.ly/2wepEHL

Eugenio FC, Santos AR, Fiedler NC, Ribeiro GA, Silva AG, Soares VP et al. Mapeamento das áreas de preservação permanente do estado do Espírito Santo, Brasil. Ciência Florestal 2017; 27(3): 897-906. 10.5902/1980509828639

Fernandes FHS, Moreira AA, Costa AO, Nery CVM. Delimitação das áreas de preservação permanente no município de Monte Azul/MG. Revista Monografias Ambientais 2015; 14(1): 154-165. 10.5902/2236130815310

Francelino MR, Silva JA. Impacto da inclinação média na delimitação de área de preservação permanente. Floresta e Ambiente 2014; 21(4): 441-448. 10.1590/2179-8087.060913

Instituto Brasileiro de Geografia e Estatística - IBGE. Belo Horizonte [map]. 1979 [cited 2019 May 20]. Available from: https://bit.ly/2WSA0J8

Instituto Brasileiro de Geografia e Estatística - IBGE. Acuruí [map]. 1977a [cited 2019 May 20]. Available from: https://bit.ly/2VRRKYF

Instituto Brasileiro de Geografia e Estatística - IBGE. Rio Acima [map]. 1977b [cited 2019 May 20]SF-23-X-A-III-1 MI 2573-1. Available from: https://bit.ly/2VPKi0h
Instituto Brasileiro de Geografia e Estatística - IBGE. Caeté [map]. 1977c [cited 2019 May 20]. Available from: https://bit.ly/2JzoXld

Instituto Estadual de Meio Ambiente - Inea. Resolução n. 93, de 23 de outubro de 2014. Diário Oficial do Estado do Rio de Janeiro, Rio de Janeiro, RJ (2014 out. 28).

Isaaks EH, Srivastava RM. An introduction to applied geostatistics. New York: Oxford University Press; 1989.

U.S. National Aeronautics and Space Administration NASA. NASA Shuttle Radar Topography Mission Global 3 arc second. 2013 [cited 2019 Aug. 7]. Available from: https://bit.ly/31o6k8u

U.S. National Aeronautics and Space Administration - NASA, Japanese Ministry of Economy, Trade, and Industry - METI. ASTER Global Digital Elevation Model. 2009 [cited 2019 Aug. 7]. Available from: https://bit. ly/2GTbwJU

Oliveira GC. Precisão de modelos digitais de terreno, mapeamento automático de APPs em topos de morros e a eficácia do novo código florestal [dissertação]. Viçosa: Universidade Federal de Viçosa; 2015.

Oliveira GC, Fernandes Filho EI. Automated mapping of permanent preservation areas on hilltops. Cerne 2016; 22(1): 111-120. 10.1590/01047760201622012100

Silva LG, Mendonça BAF, Silva EMR, Francelino MR. Atlantic Forest scenarios under the parameters of forestry laws. Ciência e Agrotecnologia 2018; 42(1): 21 32. 10.1590/1413-70542018421003417

Soares-Filho B, Rajão R, Macedo M, Carneiro A, Costa W, Coe $\mathrm{M}$ et al. Cracking Brazil's forest code. Science 2014; 344(6182): 363-364. 10.1126/science.1246663

Tambosi LR, Vidal MM, Ferraz SFB, Metzger JP. Funções eco-hidrológicas das florestas nativas e o Código Florestal. Estudos Avançados 2015; 29(84): 151-162. 10.1590/S010340142015000200010

Valeriano MM, Rossetti DF. Topodata: Brazilian full coverage refinement of SRTM data. Applied Geography 2012; 32(2): 300-309. 10.1016/j.apgeog.2011.05.004

Victoria DC. Influência da escala em uma metodologia de delimitação automática de áreas de preservação permanente em topo de morro e montanha e adaptação do método para escalas detalhadas. Revista Brasileira de Cartografia 2010 [cited 2019 May 20]; 62(3): 479-488. Available from: https://bit.ly/2YEZ9aB 